benefit; but, if it was worth anything at all, it would improve with time.

The question of an Insurance Society under this system would not necessarily require to be considered; as those who could afford it would, as at present obtains, insure their lives either in one of the existing Insurance Companies, or in a special medical one, if this should be thought more desirable.

In conclusion, I would beg to offer one other suggestion entirely apart from the foregoing. It occurs to me, in connexion with the provident system, if any scheme should be forthcoming, that it would simplify matters to make provision only for cases of death and where members become permanently and not temporarily disabled. Professional men occupy a totally different position from the "working man": the income of the latter ceases during the whole period of an illness, that of the former continues under the assistance of a substitute. There are doubtless, however, cases in which a practice may be so small that every little extra expense is a consideration. Might not these exceptions be made cases for a special fund?

Apologising for having thus trespassed upon your valuable space,

June, 1873. I am, Sir, yours faithfully, a Graddate.

\section{TREATMENT OF DERMATOPHYTA.}

To the Editor of THE IAANCET.

SIR,-The obstinacy with which dermatophyta of ten resist treatment, and the tendency they have to crop up in a fresh place when the hopes of the surgeon are high, and the fears of the patient are soothed into the belief that he has seen the last of the old plant which has been living upon him so long, must have occurred to everyone who has treated many cases of fungoid skin disease. The severer parasiticides may, it is true, eradicate the mischief, but when the face is attacked such remedies are worse than the disease, and in such cases you may paint, you may rub, you may dose as you will, but the end is-vegetation. There is a plan, however, which is generally successful, and which appears to fulfil the requirements of curing quickly, safely, and pleasantly, which is simply to exclude air, and, it is well to add, light from the surface of the affected spot, when it will be found that the fungus in a short time perishes. The best application is, perhaps, a solution of carbolic acid in Canada balsam. If this be laid on warm with a camel'shair brush, and after being allowed to dry, tinted blacks with a little Indian ink, the fungus will be destroyed, and the patient cured in about a fortnight. I have used a solution of carbolic acid in the proportion of one to ten of Canada balsam, but if necessary the balsam will take up a greater quantity.

Manchester, June 2nd, 1873.

$$
\text { I am, Sir, yours obediently, }
$$
S. Messenger Bradley.

\section{FOREIGN BODY IN THE GLOTTIS.}

\section{To the Editor of THE LANCET.}

Sir,-The following case may be of some interest to your readers, as $I$ am not aware of such a large substance having been known to enter the air-passages.

On the afternoon of Whitmonday last, a man, thirty years of age, who had been "enjoying himself" with some friends at the Crystal Palace, visited a friend's house, where he sat down to a dinner of cold shoulder of mutton. $\mathrm{He}$ had just commenced eating, when he jumped up from his seat at table as if about to vomit; he, however, got only to the door, where he sank down and was soon found to be dead.

No medical assistance was immediately procurable, and no accurate judgment could be formed as to the cause of death.

A coroner's inquest was held upon the body, and adjourned that a post-mortem examination might be made, which I performed with the assistance of $m y$ friend Dr. Stutter.

All the cavities were opened and examined, and found to be healthy. The larynx and trachea were removed, and upon lifting the glottis a foreign body appeared, which, upon being removed, was found to be a piece of meat measuring three inches in length by an inch and a quarter in diameter, and weighing five drachms.

This enormous morsel must have been drawn in by some powerful inspiratory effort whilst in the fauces.

The coroner related a similar case where an inquest had been held upon a lady who was choked from an oyster having been drawn into the larynx; and another case in which a bluebottle fly had occasioned death in the same manner.

I am, Sir, your obedient servant,

F. E. WILKINSON.

Battle Cottage, Sydenham, 14th June, 1870 .

\section{THE DOSE OF THE MURIATE OF BARYTES.}

To the Editor of THE LANCET.

Sir,-Very recently, and by accident, my attention was called to the dose of this medicine as given in the standard works of the day, and I must say it was with much surprise I found it put down as ranging from half a grain to two grains for a dose. And it is further added, at least in some of the works, that in doses of an ounce it would prove poisonous. How such statements got into print it is hard to understand; and, as the medicine is one of great activity, I take leave to draw attention to the point. I have been in the habit of using it for many years, and can state that the proper dose is from the twelfth to the sixteenth of a grain. Very few will bear the eighth. In fact, it is very analogous to the corrosive muriate of mercury, and, if an overdose be given, it will produce precisely the same violent effects. To talk, under these circumstances, of an ounce being poisonous is simply absurd. In a very valuable and nicely arranged chart, just published by Mr. Griffiths, of the Royal College of Surgeons, he very properly calls attention to this point. I may add that originally it was as a saturated solution it was given, and that the dose was four drops, gradually increased to eight, twice in the day. I remain, Sir, yours, \&c.,

Dublin, July 1st, 1873. HenRy Kennedy.

\section{CATGUT SUTURES.}

\section{To the Editor of THE LANCET.}

SIR,-Previous to reading Dr. Ogilvie Will's paper in last week's LANCET, I imagined that carbolised catgut was coming into general use for sutures, and that its advantages were acknowledged by most surgeons.

I have used nothing except catgut for sutures for the last eighteen months in this hospital, and I am satisfied that it is far superior to silk or silver wire. I have not selected cases for its use, as Dr. Will recommends.

Dr. Ogilvie Will removes the catgut suture, and thereby, I think, deprives himself of one of its principal advantages I never remove the sutures, but find that the portion outside the skin drops off after ten days or a fortnight, whilst the remaining portion inside the wound is, I suppose, absorbed, as I never see anything more of it

I have found the following advantages from the use of the catgut suture:-1. Length of time which it remains in a wound without causing irritation, and without causing subsequent marking of skin. 2. Avoidance of operation of removal, a process always painful, and of ten attended by separation of the edges of a wound from the patient flinch ing. 3. Absence of constriction in the portion of tissue included in the suture, which is very favourable to union by first intention.

I am, Sir, yours obediently,

Lincoln County Hospital, July, 1873.

H. D. MALE, House-Surgeon.

\section{HUMAN REMAINS IN IRISH BOGS.}

To the Editor of THE LANCET.

SIR,-Peat bogs being now extensively utilised for fuel in lieu of coal, other instances of human remains may from time to time be discovered. I therefore beg to forward you what seems to me a simple solution of the difficulty about the disappearance of the skeleton in the two interesting cases you lately recorded. 
Moss water contains traces of nitric acid, and being very soft, and therefore solvent, as soon as post-mortem change and the resultant gases ruptured the integument the process of solution of the phosphates of lime and magnesia and the carbonate of lime in bone would begin. The remains last discovered being those of a female, the bones would have less earthy matter in them; besides, they had probably belonged to a younger individual than those in the Omagh bog. These circumstances, together with being a shorter time in the moss, would account for their not being so thoroughly dissolved. I am, Sir, yours, \&c.,

JoHn C. MurRay, M.D.

Newcastle-on-Tyne, July 1st, 1873.

\section{THE SIR JAMES PAGET TESTIMONIAL.}

\section{To the Editor of The Lancet.}

Sir,-Nearly two years ago I gave a subscription towards the testimonial to Sir James Paget. With the exception of having seen Mr. Millais' picture in last year's Academy, I have never been able to obtain the slightest information concerning that testimonial; but living in hope, I have been postponing a visit to London in order that I might have the pleasure of seeing the most respected and popular teacher of the day receive a testimonial from his old pupils. Judge, then, my surprise and disappointment when I read in TrE LANCET of the 28 th inst.:-“On Thursday afternoon last, a large and fashionable company of ladies and gentlemen assembled in the Great Hall, St. Bartholomew's Hospital, to witness the testimonial presentation to Lady Paget," \&c. As far as I can find, all other subscribers in the provinces were left as much in the dark as myself. Sending circulars to all the subscribers might have been troublesome and expensive, but surely the insertion in a prominent position in THE LANCET of a short notice giving the date of the presentation would have been neither one nor the other.

If the gentlemen who manage these things in London treat provincial subscribers in this cavalier manner, it must have a great effect in destroying their interest in their old school and in their old teachers.

June 30th, 1873. I am, Sir, yours faithfully, AN OLd Bart's MaN.

\section{UNPROFESSIONAL ADVERTISING.} To the Editor of THE LANCET.

Sir,-Now that the College of Physicians have not only confirmed but augmented the force of the resolution come to by the College of Surgeons relative to medical men advertising their professional works in the non-medical press, it behoves all those who wish to see their profession purged of this great scandal to be prepared, each in his individual capacity, to act up to these resolutions. Much power is in the hands of the fellows of the Colleges to carry out the decision of the authorities of the Colleges. I will suggest some ways by which this may be done:-Let no fellow of the College of Physicians vote for any candidate for the fellowship who is tainted with this dishonour. Let the fellows grant none of "the honours of their College" to any such that may be among them. Let no fellow of the College of Surgeons vote for any member for that Council who may have thus offended. The Council of the College of Surgeons have in their hands the best gifts of the profession-the presidentship, the examiners, and the professors. Let them vote no man into any of these offices known as an habitual advertiser, notwithstanding he may say he has left all the advertising to his publisher; by no right-minded man will this be held as a valid excuse. Such a one has had all the advantages that advertising brings; let him now feel what the disadvantages are.

I am, Sir, your obedient servant,

"Judex Damnatur cum Nocens Absolvitur." Jane 21st, 1873.

Last week a baker was fined $£ 5$ and costs for selling bread adulterated with alum.

\section{(19bituratp.}

\section{DR. OTTO WUCHERER.}

The European, creole, and indigenous population of Bahia have to lament the loss of a highly accomplished and indefatigable practitioner in Dr. Otto Wucherer, who died there in the first week of May. He was born in Portugal, in the city of Oporto, in July, 1820. His father was a native of Würtemburg and his mother was a Dutch woman. At an early age he came to Bahia with his father, who was principal of an inportant mercantile house in that city. When nine years of age he was sent to Hamburg for his education, but shortly thereafter his father's death so straitened the family means that he had to take employment in a shop. He was enabled, however, to go to Tübingen, and entered on the study of medicine, in which faculty he graduated there as Doctor. He afterwards came to London, and held for some time the post of assistant-physician to St. Bartholomew's. From London he proceeded to rejoin his family at Lisbon, and after for a short time engaging in practice there, he went to Bahia in 1843.

He practised in Nazareth and Cachoeira, and left the most pleasing recollections behind him. He then established himself in Bahia city, where, with but few intervals, he remained till his death. He was twice married, his first wife falling a victim to yellow fever in 1853 ; while the second (a sister of the first) is now residing in Stuttgardt superintending the education of his only son.

He was a member of numerous scientific bodies in Europe and the United States. He was also a Fellow of the Imperial Academy of Rio Janeiro. He possessed not a few decorations and marks of royal esteem from Austria, Spain, and Brazil.

The Gazeta Medica da Bahia is indebted to him not only for its origin, but for numerous able contributions, in which his genius for inductive research stands prominently forth. Among these, we may signalise the paper on "Cançaço" or "Opilaçao" (a sort of cataract to which negroes are greatly subject, and which he traced to the existence of a parasite); and that on "Hæmaturia Endemica" (the milky or bloody urine common in hot countries, and also due to the presence of a worm). These articles were highly appreciated in Europe, particularly by Küchenmeister and other leading helminthologists.

He was cut off in his fifty-third year, just as he was on the eve of commencing a new series of researches on Brazilian diseases. The medical practice of that empire, which has of late years made such rapid strides, owes its chief impulse to him. IIe loved Bachia like a second country, and there his mortal remains will rest.

\section{JOHN CHARLES SAVERY, M.R.C.S., L.S.A.}

$I_{T}$ is with deep regret that we record the death of $\mathrm{Mr}$. John Charles Savery, of Hastings. This sad event had been anticipated for some months past by his most intimate friends, but to the majority of those who knew him it came as a shock. Mr. Savery was a native of Hastings, and had practised as a surgeon in that borough, in conjunction with his father, since 1857. His kindly nature and practical good sense had endeared him to all who had the privilege of his acquaintance, and his services in connexion with many of the useful institutions of Hastings and St. Leonards will not soon be forgotten. Naturally energetic, as well as unselfish and kind, he threw himself zealously into every good work which engaged his attention, and never failed to secure the esteem of his coadjutors in every enterprise to which he devoted himself. He was at one time a faithful attendant on the poor as one of the medical officers of the Union, and was to the last popular as the surgeon of the Foresters', the Druids', and the South of England Benefit Societies, and of a club at Silverhill. He held a commission in the Rifle Corps, and was honorary surgeon to the Volunteer Fire Brigade. He was an early member of the local Philosophical Society, and one of its warmest supporters. He had been President of the Hastings Mechanics' Institution, and was at the time of his death one of its vicepresidents. He was also a member of the St. Leonards 